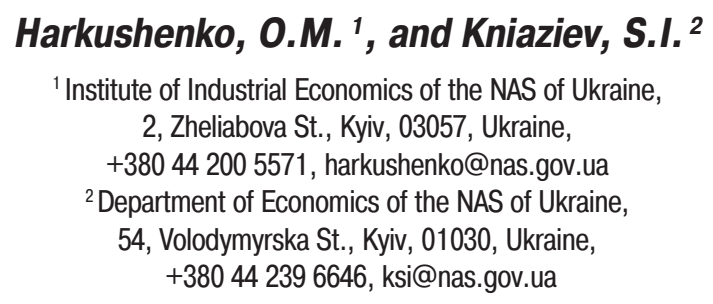

\title{
ANALYSIS OF ECONOMIC AND MATHEMATICAL MODELS OF INFORMATION AND COMMUNICATION TECHNOLOGY (ICT) EFFECT ON THE PRODUCTION OUTPUT: DOES THE SOLOW PARADOX EXIST?
}

Introduction. The development of information and communication technology (ICT) and digitalization of the society, which have been spreading around the world as a result of swiftly growing smart industry (Industry 4.0) are usually associated with an increase in production output and labor productivity and a reduction in manufacture and customization costs.

Problem Statement. According to the Solow Paradox (1987), investments in computer equipment and technology are not accounted in economic statistics on increasing labor productivity as a result of computerization, which undermines the conception of favorable impact of electronics on production output and labor productivity.

Purpose. To develop requirements for improving the economic and mathematical models for measuring the ICT impact on production output, based on the analysis of the advantages and shortcomings of the existing models of the computer technology and software effect on production output and the peculiarities of ICT development.

Materials and Methods. The historical method for analyzing the development of models of ICT impact on production output, the comparative analysis of existing economic and mathematical models to determine the approaches to the selection of factors influencing the performance indicators, and the analysis of arrays of the initial statistic data.

Results. Analyzed models and the course of their development have shown a favorable impact of ICT on production output and labor productivity. The Solow Paradox is explained by the fact that the share of computer equipment and technology in corporate fixed assets in the late 1980s - the early 1990s was insignificant, as well as by the lack of reliable statistics at that time and an imperfect methodology for its analysis. With the development of statistics as science and with the spread of computer equipment and technology, the Solow Paradox has been rejected in new models of ICT impact on production output.

Conclusions. A set of models that take into consideration the institutional features of the national economic development, the life cycle stages, and the degree of implementation of digital technologies shall be used in order to clarify the ICT impact on production output and labor productivity. The models of ICT impact on production output need to be further elaborated for taking into consideration the specifics of development of cutting-edge information technologies.

Keywords: information and communication technology(ICT), digitalization, the Solow Paradox, modelling, and production.

At present, the world is undergoing significant transformations associated with the transition to a new technological process within the frame-

(C) HARKUSHENKO, O.M., and KNIAZIEV, S.I., 2019 work of the Fourth Industrial Revolution, also known as "smart industry." This transition is based on the cyber-physics systems, information and communication tech-nologies (ICT), and the equipment on which they operate $[1,2]$. This 
large-scale penetration of electronic digital (unlike analog) equipment in all spheres of public life is called "digitalization".

Digitalization of economy is widely believed to contribute to the improvement of social welfare through a gain in labor productivity, which contradicts the so-called Solow paradox, according to which ICT and electronic devices have no favorable effect on production output and/or productivity of labor [3].

In economic science, calculations and models are tools to eliminate doubts. However, the phenomenon of economy digitization is so new that the world has been still debating its definition and concepts used (ICT, ICT infrastructure, etc.). This is confirmed by regular conferences and research of leading world organizations (for example, the Organization for Economic Cooperation and Development (OECD) [4], the International Monetary Fund [5]).

In order to specify the research object, within the framework of this research, in the broad sense, digital economy is defined as a combination of types of economic and social activities carried out on a global scale in close cooperation, on the basis of advanced ICT and cyber-physics systems with widespread use products of the ICT sector and ICT infrastructure [6], and in the narrow sense, as a synonym of the ICT sector $[7,6]$.

Despite the problem with the nomenclature, there are economic and mathematical models through which attempts have been made to determine the ICT impact on production. The analysis of some of these models, the identification and comparison of their advantages and disadvantages, are the framework for developing the economic mathematical models for determining the impact of ICT and elec-tronic devices on production output.

\section{HISTORY OF SIMULATING THE EFFECT OF SCIENTIFIC AND TECHNOLOGICAL PROGRESS ON ECONOMIC DEVELOPMENT}

The issue of determining the ICT impact on economic development is not new. ICT can be considered one of the manifestations of scientific and technological progress (STP, and Robert Solow was the first who attempted to accurately estimate its effect on productivity [8]. In 1956, he proposed to multiply the Cobb-Douglas production function by a technological variable that is increasing scale factor $\mathrm{A}(\mathrm{t})[8,85]$, assuming that it varies according to the exponential law.

According to Solow, separate changes in technology and engineering do not have any significant effect on production, and therefore are ignored by scientists. The STP impact on economy is gradual and smooth, which means that STP has a neutral effect on the production function.

These modifications of the Cobb-Douglas production function are developed within the framework of the neoclassical economic theory that deals with full employment economics, and even if one of the production factors changes, an equilibrium condition is established over time [8, 91].

In $1957, \mathrm{R}$. Solow made an attempt to quantify the STP impact on economic development [9]. As a basis, he took the Cobb-Douglas production function with his modification that takes into consideration the technological change factor. As well, the research was based on the neoclassical theory, but, unlike in previous one [8], the researcher widely used econometrics tools to determine the coefficients of the production function and to directly estimate the STP impact on labor productivity.

In this research, the calculations were made for the U.S. economy in the period of 1909-1949. Statistical data (output per unit of labor (manhour), capital per unit of labor, share of capital in the total cost of property) and calculations were limited to private sector economic activities, except for agriculture, which enabled avoiding the estimation of the share of production of the government sector and making the initial statistical data more homogeneous. That is, in research [9], Solow estimated the changes in labor productivity in the private sector of the U.S. economy under the influence of STP.

Solow emphasized that the statistical data he used to build his model were approximate and, 
some-times, there were no available data at all. Therefore, he corrected and changed the available statistics for his needs, which, as he himself noted, was definitely wrong [9, 314].

The researcher concluded that STP had a certain positive impact on the growth of production, in partic-ular, on average, in 40 years (19091949), the technological progress contributed to $1.5 \%$ annual growth of labor productivity in the private sector of the U.S. economy. However, the global crises (World Wars, etc.) caused reverse trends. In general, proceeding from all abovementioned considerations, Solow made a conclusion on the neutral effect of STP on production output.

Solow's research $[8,9]$ became the first important step towards determining the STP impact on produc-tion, but from the standpoint of modern economic science and statistics, they have several shortcomings that should be taken into account in modern economic and mathematical models.

So, Solow noted that he used approximate statistical information that he arbitrarily adjusted for his needs and did not take into account wear and depreciation at all because of the lack of appropriate methods for estimating the amount of depreciation at that time. At present, the methods for collection, and formation of statistical information and its accuracy have improved significantly.

In the Solow models, inflation was neglected, and statistical information for the model was given in actual prices, which affected the accuracy of the simulation results, since the inflation factor effect was accumulated during the simulation period.

Solow chose to simulate a long period of 40 years, which, from the statistics standpoint, would result in a better agreement between the simulation results and the reality, as compared with a shorter period. However, the development of real economies differs from mathematical and statistical systems. Thus, during the analyzed period, the United States experienced the effects of several force majeure circum-stances that affected the employment rate, the ability of private sector to invest in capital, and the total production output of the private sector. To eliminate statistical errors in simulation, it is more appropriate to choose periods with a relatively stable economic situation.

Solow's model is based on the assumption that STP develops in a gradual way, but, as it is known from historical experience, this assumption is wrong: as a rule, STP can develop rapidly ${ }^{1}$.

Since the model deals with economy as a whole, partly these sharp changes are eliminated due to the simultaneous existence of many technological curves in all sectors of economy. However, as Solow noted in [9], in 1943-1949, there was reported a sharp increase in production output (in comparison with that in the rest of the period under review), which he explained by inadequate statistical data or excessive use of capital during the Second World War. However, this can be interpreted as a sign of transition of the entire economy to a new technological curve.

In 1987, the development of information technology and electronic equipment (analog, digital, digital, with analogue elements) caused a new wave of attempts to simulate the effect of STP, in particular, electronics and software products, on production output. Again, all of them were initiated by R. Solow.

In his review of Manufacturing Matters: Myth of the Post-Industrial Economy by S.S. Cohen and J. Zysman [10] Solow reasonably criticized the authors for suggesting a hypothesis and taking it as evidence without any proof. One of the assumptions on which this hypothesis was based was that the de-velopment and implementation of computer equipment and programs stimulates growing productivity. However, for unknown reasons, in the U.S., this was not the case. So, in the authors' opinion, the problem of insufficient

${ }^{1}$ R. N. Foster described gradual technological development as motion along a technological S curve, while rapid swift development was defined by him as technological jump and transition to a new S curve [11, 78-79]. Hereinafter, Foster's terms for technological development are used. 
growth in productivity was caused by some other factors rather than by electronic equipment and software.

Solow denied this as he said, "You can see the computer age everywhere but in the productivity statistics" [3,6]. Being decontextualized, this statement was called the Solow productivity paradox and caused numerous research publications whose authors, with the help of economic and mathematic models, tried to prove or to refute Solow's opinion and to estimate the effect of modern ICT and electronic equipment on economies in terms of various aspects of its development (increase in GDP, value added, labor productivity, etc.). Below, the author analyzes some selected works.

\section{ANALYSIS OF MODERN ECONOMIC AND MATHEMATIC MODELS OF ICT IMPACT ON PRODUCTION OUTPUT}

It should be noted that in addition to the economic and mathematic models whose authors tried to test, to refute or to confirm the Solow paradox, there are researches that explain, on the standpoint of logic, why statistics on labor productivity do not show a gain in productivity as a result of investments in ICT sector.

J. Triplett has conducted a thorough research of this issue and explained how the neglected factors af-fect the results of the economic and mathematic models developed by other authors and thereby extend the life of the Solow paradox (the Jorgenson-Stiroh model (1994-1995), P. McCarthy (1995), etc.) [12]:

1. You don't see computers "everywhere," in a meaningful economic sense. In 1998-1999 (when the research was published), computers and information processing equipment were a relatively small share of GDP and of the capital stock. For example, in 1993, their share in the U.S. corporate capital stock amounted to $14 \%$. Therefore, when creating the economic and mathematic models, it was neglected, which made obtaining correct results impossible [12, 311-313].

2. You only think you see computers everywhere. At least, in 2000, government hedonic price inde- xes for computers fall "too fast," according to this position, and therefore measured real computer output growth is also "too fast" [12, 315-318].

3. You may not see computers everywhere, but in the industrial sectors where you most see them, output is poorly measured. Examples are finance and insurance, which are heavy users of information technology and where even the concept of output is poorly specified [12, 318-321].

4. Whether or not you see computers everywhere, some of what they do is not counted in U.S. Department of Labor economic statistics [12, c. 321-322]. Many innovations in electronics and software aim at making their use simpler and more convenient. However, such "user friendly" innovations require greater power of electronic devices on which they are implemented: larger amount of RAM, more operations per unit of time. These characteristics are not shown, at least, in the economic statistics related to labor productivity. Also, where does one count the value of increased convenience and better user interface in economic statistics, how do these innovations help to increase labor productivity, and how much time and effort does the employee need to master the proper skills?

In addition, due globalization and ICT expansion, corporations have many opportunities to transfer manufacturing facilities and part of financial transactions to other countries for reducing the tax liabili-ties. In this case, the cost of innovation in ICT sector and the results obtained through such innovations may be accounted in statistical data of other countries where manufacturing facilities are located or fi-nancial operations are carried out, not in the country of the head office that manages the manufacture and controls the costs. National statistical services and models for estimating the ICT impact on the economic development of an individual country do not take into account such a way of doing business by corporations, which also affects the simulation results.

5. You don't see computers in the productivity statistics yet, but wait a bit and you will [12, 310]. 
The idea that the productivity implications of a new technology are only visible with a long lag. However, as soon as the S curve begins to ascend, the economic results of new technology become more visible, which can be accounted in the statistics.

In addition, since the emergence of a new phenomenon (e.g., ICT), within a certain period (that differs from case to case), there is some uncertainty in methodology for collecting and analyzing statistical data, as well as in the terminology that describes it. It is extremely difficult to simulate phenomena for which there are so many uncertainties. At present, in the field of ICT, the situation with terminology and statistics has been, at least, partially resolved, and modern economic and mathematic models for measuring the effect of ICT and electronics on productivity are expected to more adequately reflect the reality.

6. There is no paradox: some economists are counting innovations and new products on an arithmetic scale when they should count on a logarithmic scale. The arithmetic method makes it possible to count "new things". Therefore, while comparing the past with the present, some researchers have impression that previously there were produced more new things at a lower cost, which confirms paradox of Solow. However, it is more appropriate to judge the pace of technological changes using the logarithmic method. In this case, the situation turns upside down [12, 326-328].

These considerations have been taken into account in new models proposed by other researchers.

One of the most well-known (based on the citation statistics) among economic and mathematic models for measuring the ICT impact on economic development is the econometric model proposed by D. Jorgenson and K. Stiroh [13, 14].

It is based on the Cobb-Douglas production function as modified by Solow. The JorgensonStiroh modification was to disaggregate the production function components and to take its logarithms. In particular, yield $Y_{t}$ is introduced by them as the total of investments (investment yield) in a particular year $I$, accumulated capital $K_{t}$, labor input Lt, and consumption (yield of consumer goods) $C_{t}[13,6]$. The production function has the following form:

$$
\begin{gathered}
\overline{w_{I, t}} \Delta \ln I_{t}+\overline{w_{C, t}} \Delta \ln C_{t}=\overline{v_{K, t}} \Delta \ln K_{t}+ \\
+\overline{v_{L, t}} \Delta \ln L_{t}+\Delta \ln A_{t}
\end{gathered}
$$

where $A_{t}$ is variable related to the effect of ICT on production output (technological factor); $\overline{w_{I, t}}$ is average share of investments per nominal yield; $\overline{w_{C, t}}$ is average share of consumption per nominal yield; $\overline{v_{K, t}}$ is average share of capital per nominal yield; and $\overline{V_{L, t}}$ is average share of labor input per nominal yield; $\overline{w_{I, t}}+\overline{w_{C, t}}+\overline{v_{K, t}}+\overline{v_{L, t}}=1$; symbol $\Delta$ denotes the first derivative.

D. Jorgenson and K. Stiroh tried to measure the effect of labor input, capital, and information devices and technologies on the U.S. economic growth. The estimates were done for the period of 1973-1998 for the whole economy of the country. The costs of computer and telecommunication hardware and software were included in the capital component. The statistical data were presented in a comparative manner (1996 is the reference year) [13, 8].

Having transformed (1) and defined that $H_{t}$ is labor input for period $t, y_{t}=\frac{Y_{t}}{H_{t}}$ is total yield (the total of investments and consumption) per labor input, and $k_{t}=\frac{K_{t}}{H_{t}}$, is capital per labor input, D. Jorgenson and K. Stiroh obtain the following equation for average labor productivity:

$$
\Delta \ln y_{t}=\overline{v_{K, t}} \Delta \ln k_{t}+\overline{v_{L, t}}\left(\Delta \ln L_{t}-\Delta \ln H_{t}\right)+\Delta \ln A_{t} .
$$

The researchers determined that, in 1973-1995, computers, software, and telecommunication equipment contributed an average of $0.34 \%$ annually to economic growth, in 1996-1998, their share made up $0.99 \%$; from 1990 to 1999 , the average labor productivity in the U.S. was growing, with increase in both value and capital contributing 0.49 percentage points to this growth, while the use of ICT in manufacturing industries having a share of 0.63 percentage points $[13,19]$. 
As compared with the previous researches criticized by J. Triplett [12,312], in the model under review, D. Jorgenson and K. Stiroh added software and communication equipment to the cost of capital and updated statistical data, most of which they did not have before (1994-1995). Consequently, the results were more optimistic than in the previous model, with the contribution of computer technology to the gain in production for 1990-1996 estimated at $0.12 \%$ annually [13].

In 2003, D. Jorgenson, K. Stiroh, and M. Ho revised their model, expanded their calculations to some OECD countries (Australia, Canada, Finland, France, Germany, Italy, Japan, United Kingdom, and USA), and developed forecasts of the economic development of these countries through the introduc-tion of ICT. In the revised model, the capital embraced computer, telecommunication equipment, and software [14,6], with the dual nature of ICT and electronics taken into consideration (for the ICT sec-tor, they are products and part of its fixed assets, while for the rest of the economy they are component of capital) [14,5].

Using this model, the researchers predicted that, from 2003 to 2013, production in the OECD countries would increase by an average of $2.78 \%$ annually, with $1.78 \%$ of this growth credited to the ICT sector and investment in ICT equipment and software in other sectors of the economy $[14,15]$.

Despite the improvements, as compared with the model of 1994-1995, the revised JorgensonStiroh model still have some shortcomings:

1. The authors analyzed a long period of time (1973-1998), including the periods of economic instabil-ity (for example, the two waves of the energy crisis). Such force majeure circumstances could affect the simulation results: the error could accumulate, which could affect the accuracy of the model.

2. The Jorgenson-Stiroh model does not take into account the technological curves, as a result of which the real (rather than the book) value of the ICT sector products and fixed assets related to software and electronic equipment and accounted on balance sheets of corporations may be significantly underesti-mated. The model includes the price indices for ICT products, but only for new products, with those for already used ones neglected.

For the ICT sector and its products, consideration of technological S curves is crucially important. So, according to the Moore law and estimates based on it, in 1970-2000, processors underwent, at least, 14 significant technological changes (performance, miniaturization and, accordingly, the manufacturing technology) [15, 22]. It can be assumed that, in this period, other components of digital equipment and software as well were subject of significant changes that affected their cost and the relative value of their older counterparts.

In the case of simulating the ICT impact on economy or industries, the neglect of lag between the time of investment in ICT and the time when the investment starts to return (that is, the lower part of the technological curve), which is often considered a disadvantage of model (for example, in [16]), is deemed a particular case of the broader problem related to ignoring the technological curves. It is ad-visable to include such a time lag into models of individual corporations or industries, where the time of investment and return can be relatively accurately fixed and studied. In the economy as a whole, at the same time, there are many technological curves; different corporations and even industries are "located" in different parts of technological curves or even in different technological curves. Therefore, this time lag is indistinct, and its limits are not accurately definable. In this case, it is more appropriate to focus on the frequency and speed of radical technological changes that are massive transition of corporations and entire industries to a new technological curve.

Proceeding from the above, that that some authors $([16,17])$ describe as taking the time lag into account while measuring the ICT impact on production should be interpreted as accounting such a massive transition from one technological curve to another in the statistical data. 
Russian researcher V.V. Platonov pointed out another feature of the Jorgenson-Stiroh model [16]. He noted that the econometric studies of panel data by D. Jorgenson and K. Stiroh brought even more par-adoxical results than the Solow productivity paradox: they showed that ICT had a positive effect on economic growth and productivity, but adversely affected the overall performance of production factors (i.e., capital and labor) for the United States. This contradiction is explained by imperfection of the methodology for quantitative studies, which existed at the time, in particular, by the use of unsteady time series [16, 31].

With the development of econometric methodology, this contradiction can be overcome. M. O'Mahony and M. Vecchi have carried out a similar study for measuring the ICT impact on the overall productivi-ty of the factors of production [17]. Their research is based on the existing modifications to the Solow model, in particular, on the Jorgenson-Stiroh model. For the purpose of simulation, 31 economic activi-ties in the United States and 24 economic activities in the United Kingdom, agriculture excluded in both cases, within the period 1976-2000 were chosen.

The O'Mahony-Vecchi model takes into account the fact that corporations from different industries in-vest in different types of ICT and, therefore, the share of ICT in the structure of their capital differs as well.

In the O'Mahony-Vecchi model, yield (denoted as Y in the models of Solow and other researchers) is defined in terms of value added, since at the time of the model development there was no reliable sta-tistic data on the gross output in the United Kingdom. The authors classified capital into ICT-capital (computers, software, and communication equipment) and non-ICT capital (the rest of the capital). Un-like the previous models, M. O'Mahony and M. Vecchi attempted to take into account the depreciation of fixed assets and faster aging of ICT capital as compared with the non-ICT capital. The latter was done with the use of ICT price indexing models.
The authors of the model state that for analyzing a rather long period of time (25 years) and different types of industries (55) it is inappropriate to use the least-squares method as other authors did (in particular, in the models from $[9,13$, and 14]), because this method works well if all variables are station-ary and corporations are homogeneous, which was not the case in reality). M. O'Mahony and M. Vecchi have suggested using a method that takes into account the heterogeneity of time series with pre-test of data for time invariance and cointegration $[17,4]$.

These researchers have shown that when using the conventional methods for calculations based on the collected data, one can obtain simulation results that are identical to those of J. Jorgenson and K. Stiroh: in the United States and the United Kingdom, in 1976-2000, the average contribution of in-vestments in ICT to the value added growth was $2.28 \%$ annually, whereas that to the total productivity of the factors of production accounted for $1.22 \%[17,8]$. However, using a more sophisticated calcula-tion method, it has been found that if the total increase in value added is assumed $100 \%$, then in the United States and United Kingdom, in 1976-2000, there was a gain of $40 \%$ (not $20 \%$ as defined in the previous models) due to investments in ICT $[17,19]$. In the period under review, for the two countries the marginal return on investment in the ICT capital totaled $22 \%$, while that in the other capital made up only $12 \%[17,20]$. Moreover, in the United States, where corporations started to invest in ICT earlier and on a larger scale as compared with the United Kingdom, the marginal return on investment in ICT capital reached $51 \%$, while in the United Kingdom it accounted for $20 \%[17,21]$.

M. O'Mahony and M. Vecchi note that the results of their calculations may seem too optimistic because they select few corporations and industries. However, a significant advantage of their research [17] is that they have proved in a realistic manner that incorrect research method may adversely affect the final results. The researchers 
also point out that the paradoxical results obtained by J. Jorgenson and K. Stiroh are explained by the neglect of time lag between investment in ICT and the point when the investment starts to return, which is accounted in statistical data. Although, as noted above, if the object of simulation is not an individual corporation or industry, the statistical data show the transition to a new technological curve and a technological gap rather than a time lag between the investment and the start of return on it. This means, the statistical data may reflect changes in the very nature of innovation (for example, massive transition from analog devices to hybrid or digital ones, generally named "computers"). Such nuances of technological changes require more attention when developing models, because they can also affect their reliability.

At the same time, as noted by V. Platonov [16, 32], the O'Mahony-M. Vecchi approach has the following limitation:

1) it cannot explain causal relationships (that is, one cannot find out which of the reported phenomena is the cause, and which is the consequence);

2) within its framework, it is impossible to analyze the channels and mechanisms of ICT impact on productivity;

3) being based on the neoclassical theory, it does enable to analyze innovative development.

The last disadvantage is connected with the fact that the authors do not realize the importance of technological S curves and, therefore, do not take into account the particular features of technological development in their model.

Despite the fact that M. O'Mahony and M. Vecchi has proved the inexpediency of using the old statistical analysis methodology, the JorgensonStiroh model and the calculation method used by them has been still practiced because of the complexity of calculations based on the O'Mahony-Vecchi method or because of the research works by D. Jorgenson and K. Stiroh have been better accessible to the public. For example, the same approach to simulating the ICT impact on production output as exemplified by Germany has been used by Ukrainian researchers A. Madykh and O. Okhten [18].

In addition to the models for identifying and measuring the ICT impact on the economy, economic development, and labor productivity at the national or group level, there are models that address similar problems at the microlevel. An example of such a model is the econometric model of E. Brynjolfsson and L. Hitt [19], where, within the framework of the neoclassical theory, the effect of computerization on production output and labor productivity is determined based on information about the activities of 527 large U.S. corporations in 1987-1994.

These authors proceeded from the modified Jorgenson-Stiroh model $([13,14]$, in which they explicitly separated the ICT and the non-ICT capital $^{2}$, and also noted that the results depend on industry to which the corporation belongs.

In general, the Brynjolfsson-Hitt model has the following form:

$$
Q=A(i, j, t) K^{\beta_{K}} L^{\beta_{L}} C^{\beta_{C}},
$$

where $Q$ is added value of corporation; $K$ is cost of conventional (non-ICT) capital; $C$ is cost of ICT capital; $L$ is labor; $t$ is time variable, $t=\overline{1987,1994}$; $i$ is number of the corporation analyzed, $i=\overline{1,527}$; $j$ is industry (type of economic activity) to which the corporation $i$ belongs; $A$ is variable showing the time dynamics of the difference in value added amounts among the corporations, which is not related to changes in the use of input resources (labor, ICT capital and non-ICT capital); $\beta$ are parameter of non-ICT capital elasticity $\left(\beta_{K}\right)$, labor $\left(\beta_{L}\right)$, and ICT capital $\left(\beta_{C}\right)$.

While making the analysis, the authors converted the actual values into their levels by taking logarithms (3). To simplify the presentation, the variables in logarithmic form were deno-

${ }^{2}$ Unlike in the Jorganson-Stiroh and O'Mahony-Vecchi models, in this model, the ICT and non-ICT capitals are separate variables in the function with different power indexes instead of being a part of one variable (capital as a whole) with a common power coefficient. 
ted by small symbols ${ }^{3}$, with indexes denoting the corporation $(i)$, time $(t)$, and industry $(j)$ neglected, except for the cases when it was required for clear understanding:

$$
q=a(i, j, t) \beta_{K} k \beta_{L} l \beta_{C} c .
$$

In the Brynjolfsson-Hitt model, the data are presented in a comparable view and adjusted for price in-dices. The error due to the inaccuracy of statistical data is allowed for, although the authors believe that the statistical information is correct.

Having compared the changes in $a, q, l$ with time, E. Brynjolfsson and L. Hitt made the following conclusions:

1) ) the ICT capital strongly correlates with growth in labor productivity; as time interval increases (from 1 year to 7 years), the correlation gets stronger, which can be explained by the adaptation of corporation's organizational structure to new technologies;

2) the industry to which the corporation belongs and the period during which the ICT capital is used affect the contribution of computerization to increasing labor productivity;

3) for any industry, the use of computers leads to an increase in labor productivity;

4) at the level of corporations, investments in ICT capital for the period under review (7 years, 1987-1994) led to a $0.25-0.5 \%$ increase in the value added;

5) outdated fixed assets, difference in existing technological infrastructures, and approach to investment in ICT used by a particular corporation may affect the desire of its management to invest in new ICT capital or the ability to quickly introduce this capital into operation at a particular corporation.

E. Brynjolfsson and L. Hitt emphasize that their calculations of the effect of ICT capital on labor productivity describe the situation only in the private sector, including rent seeking, and do not cover spillovers of labor productivity. So,

${ }^{3}$ I.e., $\log K$ is denoted by Brynjolfsson and Hitt as $k$. based on these calculations, it is impossible to determine whether the effect of ICT capital on the whole economy is greater or less than that on the private sector.

Since the model of E. Brynjolfsson and L. Hitt is based on the principle and methodology of the Jorgenson-Stiroh model, it has the same problems, although in addition to the least-squares method, the authors use the correlation-regression analysis. Despite the fact that E. Brynjolfsson and L. Hitt present the statistical data in a comparable form and adjust them by price indices, they do not consider such factors as deterioration of fixed assets and technological cycles [19].

One more group of economic and mathematical models aims at measuring the scale and identifying trends of the digital economy rather on determining the effect of digitalization on national economy or activities of individual corporations. In particular, such a model is proposed by Caixin Media Company Ltd. (Beijing) [20]. The purpose of its development is to estimate the effect of digital economy on GDP, to compare the scale of digital economy in different countries, and to make recommendations on the directions for its further development [20, 2-3]. At the same time, in the given model, the term "digital economy" is used in its narrow sense and means the ICT sector.

The Caixin model presented in [20] is a variation of the Cobb-Douglas production function in the linear form. The function uses proportions and shares of the input parameters (labor, capital, technological innovation) to obtain a certain index that, according to the authors of the model, characterizes the development of the digital economy of China. The model has the following form:

$$
\begin{gathered}
\text { InDigitalEconomy }=\alpha \cdot L+\beta \cdot C+ \\
+(1-\alpha-\beta) \cdot T I,
\end{gathered}
$$

where InDigitalEconomy is index that describes the development of the digital economy; $L$ is labor; $C$ is capital; $T I$ is technology innovation; $\alpha, \beta$ are coefficients that characterize the shares of the input parameters in the resulting index. 
The input parameters of the Caixin model have a complex structure, as the capital factor consists of "proportion of venture capital in the digital sector", "proportion of auction", "proportion of firm's registered capital," and "proportion of newly registered capital in the digital sector"; the technology innova-tion factor includes "the share of researchers in the digital sector", "the share of new inventions and patents in the digital sector", and "patent conversion rate in the digital sector", respectively. The coefficients of the input parameter shares in the resulting index have been calculated by Caixin (the method has not been disclosed). They are equal to $40 \%$ for the labor factor, $40 \%$ for the capital factor, and $30 \%$ for the technology innovation factor.

As noted by A. G. Herrero and J. Xu, nearly all of Caixin's omeasurements on the inputs are collected through big data analysis and collaboration with an anonymous online recruitment platform.

As a result of all calculations it has been determined that, in China, from January 2016 to April 2017, the growth of the digital economy reached $176 \%$.

Although most of the results from the above indices are promising in terms of measuring China's digital economy, A.G. Herrero and J. Xu point out that comparing the development of China's digital economy with other countries is impossible because of different lists of economic activities: the industries that Caixin refers to the ICT sector are different from those used, for example, by the OECD. In addition, Caixin does not introduce a detailed methodology for collecting and processing statistical information and for calculating the input parameter coefficients in the resulting index $(\alpha, \beta y(5))$. Also, it is not mentioned whether the model takes into consideration such factors as depreciation of fixed assets, inflation effect on monetary indices, changes in prices for digital products as a result of the transition from one technological curve to another, and data period. In view of this, it is difficult to make conclusions on the reliability of this proposed model.

Also, as noted by J. Triplett [12, 326-328] and R. Solow [9, 318], the accuracy of results based on the Cobb-Douglas function modification in the linear form leaves much to be desired.

Thus, to summarize abovesaid concerning the economic and mathematical models of the ICT impact on production output it can be stated as follows:

1. The fact that researchers started these simulations shows that the scientific community, manufacturers of products (providers of services), and government bodies have realized the importance of ICT for economic development.

2. The models for measuring the ICT impact on production output are mainly based on the Cobb-Douglas production function as modified by R. Solow.

3. With the help of the models it has been found that computer equipment and technology have a favor-able impact on production output. The Solow paradox is explained by a small share of computer equipment and technologies in fixed assets of corporations, the lack of reliable statistical information on the conversion of computer innovations and their use by economic entities, and by the imperfect methodology for analyzing statistical data at the time of occurrence of this paradox. As statistical science develops and the presence of computers and ICT in economy grows, the new models have denied the Solow paradox, even though most authors of such models still use outdated methods for analyzing statistical data. Currently, the actual task is not only to determine, based on the models, whether computers and ICT have an impact on production output, but also to measure this effect as compared with investments in ICT in various countries and to identify favorable conditions for the further development of ICT in specific country.

4. The main disadvantage of the majority of the analyzed models is the neglect of computer and ICT depreciation and technological cycles, which affects the reliability of the results. This disadvantage should be eliminated when creating new models.

5. Almost all of the analyzed models aim at measuring the ICT impact on output within a single country. However, there are many factors 
that influence the development of the ICT sector in a particular country and the introduction of digital products into the activities of economic entities, such as institu-tional development, specific features of economic development, existing infrastructure, etc. [1]. Therefore, it is advisable to simulate the ICT impact on economic development in comparison with other countries, taking into account the peculiarities of their development, which may require building several models in order to solve individual parts of the general problem and to find more correct solutions.

Proceeding from the advantages and disadvantages of the models analyzed above, it is understood that while developing economic and mathematical models of the ICT impact on economic development, it is necessary to take into account several nuances.

Firstly, it is necessary to specify the task to be solved with the help of economic and mathematical models (ICT impact on GDP, on performance of individual corporations, etc.).

Secondly, since the digital economy and ICT are new phenomena, there are significant differences in terminology throughout the world, on the one hand. On the other hand, the problem of measuring their impact on the economy and its components is complicated by the following factors: 1) the imperfection and incompleteness of statistical data; 2) the simultaneous existence of many technological S curves in different industries and rapid transitions from one curve to another within the economy of one country, etc. Therefore, the retrospective analysis of the digital economy and/or ICT impact on the country's economy is not feasible at the moment. In order to measure the ICT impact on production out- put and to study how the digital economy and ICT influence the interrelated development of digital technologies it would be advisable to choose a short period of time for the simulation (for example, 3-5 years, during which, according to the Moore law and analysis of changes in the ICT sector over the recent $10-20$ years, no sharp and massive transitions to the next technological curve in the world have been reported) and to compare the results with different countries having different levels of development and integration of ICT in their economies.

Thirdly, proceeding from the number of tasks and factors that need to be taken into account, it is expe-dient in the future to simulate the ICT impact on production based on several models, rather than on one equation. Using a set of models enables to determine the factors on which the development of ICT depends; to divide countries into groups depending on the availability of such factors; to parametrize the $\mathrm{S}$ curve for each group of countries and, based on this, to determine the effect on production and productivity in each group of countries.

Overlaying $\mathrm{S}$ curves that describe the ICT impact on production output of countries from different groups enables to roughly determine whether these countries from different groups are in different sec-tions of the same S curve, or they are on different curves. The first means that there is a technical gap between countries from different groups, but it is not significant and can be eliminated. The second can be a sign of a large technological underachievement as compared with the leaders and serious problems of economic development in the countries from a particular group.

\section{REFERENCES}

1. Garkushenko, O. M. (2018). Information and communication technologies in the era of the smart industry development: problems of definition and conditions of development. Econ. promisl., 2(82), 50-75 [in Russian].

2. Vishnevsky, V. P., Kniaziev, S. I. (2018). How to increase the readiness of Ukraine's industry to smart transformations. Nauka innov., 14(4), 55-69 [in Ukrainian].

3. Solow, R. (1987, 12 July). We'd better watch out. The New York Times Book Review, Vol. 36.

4. OECD Observer ministerial roundtable: Digital economy. OECD Observer. 2016. URL: http://oecdobserver.org/ news/fullstory.php/aid/5590/OECD_Observer_ministerial_round table:_Digital_economy.html (Last accessed: 15.12.2018). 
5. Measuring the Digital Economy: Staff Report. International Monetary Fund. 2018, 28 February. URL: https://www. imf.org/en/Publications/Policy-Papers/Issues/2018/04/03/022818-measuring-the-digital-economy (Last accessed: 15.12.2018).

6. Garkushenko, O. M. (2018, August). Digital economy: problems of terminology. Poster session presented at the International science and practical conference on State and prospects of development of financial and economic potential of modern enterprises, Dnipro [in Ukrainian].

7. Li, J. (2014, June). Protecting the Tax Base in the Digital Economy. UN Papers on Selected Topics in Protecting the Tax Base of Developing Countries. Paper No. 9.49 p.

8. Solow, R. (1956). A Contribution to the Theory of Economic Growth. The Quarterly Journal of Economics, 70(1), 65-94.

9. Solow, R. (1957). A Technical Change and the Aggregate Production Function. The Review of Economics and Statistics, 39(3), 312-320.

10. Cohen, S. S., Zysman, J. (1987). Manufacturing Matters: Myth of the Post-Industrial Economy. New York: Council on Foreign Relation/Basic Books.

11. Foster, R. (1987). Innovation: The attacker's advantage. Moskow: Progress [in Russian].

12. Triplett, J. E. (1999, April). The Solow productivity paradox: what do computers do to productivity? Canadian Journal of Economics/ Revue canadienne d'Economique, 32(2), 309-320.

13. Jorgenson, D. W., Stiroh, K. J. (2000, May). Raising the Speed Limit: U.S. Economic Growth in the Information Age. Brookings Papers on Economic Activity, No. 1, 188.

14. Jorgenson, D. W., Ho, M. S., Stiroh, K. J. (2003). Lessons from the U.S. Resurgence. Journal of Policy Modeling, 25(5), 453-470.

15. Moore, G. E. (2003, February). No Exponential is Forever: But "Forever" Can Be Delayed! Poster session presented at the International Solid-State Circuits Conference (ISSCC), San Francisco, USA.

16. Platonov, V. V. (2007). «Paradox Solow» twenty years later or on the study of the impact of innovations in information technology on productivity growth. Finansyi i biznes, 3, 28-39 [in Russian].

17. O'Mahony, M., Vecchi, M. Is there an ICT impact on TFP? A heterogeneous dynamic panel approach. London: National Institute of Economic and Social Research, 2003. 32 p.

18. Madykh, A. A., Okhten, O. O. (2018). Modeling the transformation of the impact of production factors on the economy in the process of smart industry formation. Econ. promisl., 4(84), 26-41 [in Russian].

19. Brynjolfsson, E., Hitt, L. M. (2003). Computing productivity: firm-level evidence. Review of economics and statistics, 85(4), 793-808.

20. Herrero, A. G., Xu, J. (2018, 17 May). How big is China's digital economy? Bruegel Working Paper, Issue 04. 14 p. URL: http://bruegel.org/wp-content/uploads/2018/05/WP04_Digital-economy_Bruegel.pdf (Last accessed: 10.09.2018).

Received 18.01.19

Revised 21.01.19

Accepted 25.01.19

\author{
О.М. Гаркушенко ${ }^{1}$, С.I. Князев ${ }^{2}$ \\ ${ }^{1}$ Інститут економіки промисловості НАН України, \\ вул. Желябова, 2, Київ, 03057, Україна, \\ +380 44200 5571, harkushenko@nas.gov.ua \\ ${ }^{2}$ Відділення економіки НАН України, \\ вул. Володимирська, 54, Київ, 01030, Україна, \\ +380442396646, ksi@nas.gov.ua
}

\title{
АНАЛІЗ ЕКОНОМІКО-МАТЕМАТИЧНИХ МОДЕЛЕЙ ВПЛИВУ ІНФОРМАЦЙНО-КОМУНІКАЦІЙНИХ ТЕХНОЛОГІЙ НА РЕЗУЛЬТАТИ ВИРОБНИЦТВА: ЧИ ІСНУЄ ПАРАДОКС СОЛОУ?
}

Вступ. Розвиток інформаційно-комунікаційних технологій (ІКТ) і цифровізація суспільства, що розповсюджується у світі через прискорений розвиток смарт-промисловості (Індустрії 4.0), зазвичай пов’язують 3 підвищенням обсягів виробництва та продуктивності праці, зменшенням відносних витрат на одиницю продукції та її кастомізацією.

Проблематика. Відповідно до парадоксу Солоу (1987 р.), інвестиції у комп’ютерну техніку та технології не знаходять відображення в економічній статистиці про підвищення продуктивності праці внаслідок комп'ютерізації виробництв, що підриває уявлення про позитивний вплив електроніки на виробництво та продуктивність праці.

Мета. Розробити вимоги щодо удосконалення економіко-математичних моделей визначення впливу ІКТ на виробництво на основі аналізу переваг та недоліків наявних моделей впливу комп'ютерної техніки та програмного забезпечення на результати виробництва з урахуванням особливостей розвитку IКТ. 
Матеріали й методи. Історичний метод для аналізу розвитку моделей впливу ІКТ на виробництво, порівняльний аналіз наявних економіко-математичних моделей щодо визначення підходів до відбору факторів впливу на результуючі показники, аналітична обробка масивів вихідної статистичної інформації.

Результати. Проаналізовані моделі у своєму розвитку свідчать про позитивний вплив ІКТ на виробництво та продуктивність праці. Виникнення парадоксу Солоу пояснюється тим, що в основних фондах підприємств частка комп’ютерної техніки та технологій була незначною наприкінці 1980-х - початку 1990-х рр., а також відсутністю на той час достовірної статистичної інформації та недосконалістю методології аналізу. 3 розвитком статистичної науки та поширенням комп'ютерної техніки та технології в нових моделях впливу ІКТ на результати виробництва парадокс Солоу було спростовано.

Висновки. Для уточнення впливу ІКТ на виробництво та продуктивність праці слід використовувати комплекс моделей, які враховуватимуть інституційні особливості розвитку економіки країни, етапи їі життєвого циклу та ступінь впровадження в ній цифрових техніки та технологій. Моделі впливу ІКТ на результати виробництва потребують подальшого розвитку, зокрема й з урахуванням закономірностей розвитку сучасних інформаційних технологій.

Ключові слова: інформаційно-комунікаційні технології, цифровізація, парадокс Солоу, моделювання, виробництво.

\section{О.Н. Гаркушенко ${ }^{1}$, С.И. Князев ${ }^{2}$}

${ }^{1}$ Институт экономики промышленности НАН Украины,

ул. Желябова, 2, Киев, 03057, Украина,

+380 44200 5571, harkushenko@nas.gov.ua

${ }^{2}$ Отделение экономики НАН Украины,

ул. Владимирская, 54, Киев, 01030, Украина, +380442396646, ksi@nas.gov.ua

\section{АНАЛИЗ ЭКОНОМИКО-МАТЕМАТИЧЕСКИХ МОДЕЛЕЙ \\ ВЛИЯНИЯ ИНФОРМАЦИОННО-КОММУНИКАЦИОННЫХ ТЕХНОЛОГИЙ НА РЕЗУЛЬТАТЫ ПРОИЗВОДСТВА: СУЩЕСТВУЕТ ЛИ ПАРАДОКС СОЛОУ?}

Введение. Развитие информационно-коммуникационных технологии (ИКТ) и цифровизация общества, распространяющиеся в мире вследствие ускоренного развития смарт-промышленности (Индустрии 4.0), обычно связывают с повышением объемов производства и производительности труда, уменьшением удельных издержек на единицу продукции и ее кастомизацией.

Проблематика. Согласно парадоксу Солоу (1987 г.), инвестиции в компьютерную технику и технологии не отражаются в экономической статистике о повышении производительности труда вследствие компьютеризации производств, что подрывает представление о положительном влиянии электроники на производство и производительность труда.

Цель. Разработать требования по совершенствованию экономико-математических моделей определения влияния ИКТ на производство на основе анализа преимуществ и недостатков известных моделей влияния компьютерной техники и программного обеспечения на результаты производства и учета особенностей развития ИКТ.

Материалы и методы. Исторический метод для анализа развития моделей влияния ИКТ на производство, сравнительный анализ существующих экономико-математических моделей по определению подходов к отбору факторов влияния на результирующие показатели, аналитическая обработка массивов исходной статистической информации.

Результаты. Проанализированные модели в своем развитии свидетельствуют о положительном влиянии ИКТ на производство и производительность труда. Парадокс Солоу объясняется тем, что в основных фондах предприятий доля компьютерной техники и технологий была незначительной в конце 1980-х - начале 1990-х гг., а также отсутствием в то время достоверной статистической информации и несовершенством методологии анализа. С развитием статистической науки и распространением компьютерной техники и технологии в новых моделях влияния ИКТ на результаты производства парадокс Солоу был опровергнут.

Выводы. Для уточнения влияния ИКТ на производство и производительность труда следует использовать комплекс моделей, учитывающих институциональные особенности развития экономики страны, этапы ее жизненного цикла и степень внедрения в ней цифровых техники и технологий. Модели влияния ИКТ на результаты производства требуют дальнейшего развития, в частности и с учетом закономерностей развития современных информационных технологий.

Ключевые слова: информационно-коммуникационные технологии, цифровизация, парадокс Солоу, моделирование, производство. 